\title{
Evaluation on Thermal Performance of Solar Water Heating System of High-Rise House in Jinan City
}

\author{
Shi Jinglei ${ }^{1, a}$, Li Zhen ${ }^{2, b}$, Li Di ${ }^{3, c}$ \\ 1Shandong Academy of Building Research, Jinan,250031, China \\ 2Shandong Academy of Building Research, Jinan,250031, China \\ 3Shandong Academy of Building Research, Jinan,250031, China

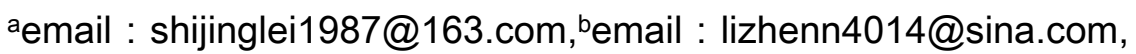 \\ cemail : 18653164200@163.com
}

\begin{abstract}
Keywords: Distributed solar water heating system Annual solar guarantee rate Solar guarantee rate Energy efficiency assessment
\end{abstract}

\begin{abstract}
The paper selects distributed solar water heating system of certain high-rise house in Jinan City as research object, its field performance test and energy efficiency assessment are made, obtains annual solar guarantee rate and conventional energy substitution quantity of solar water heating system of the building, makeseconomic benefit assessment, analyzes energy saving effect and economic benefit of the system, and gives out energy saving index and economic index. Research results show distributed solar water heating system of the high-rise building has good energy saving effect and economic benefit.
\end{abstract}

\section{Foreword}

Design, construction, management, etc. of water heating system of high-rise building in Jinan City become increasingly normalized, but since actual operating performance and theoretical design situation of solar water heating system have inevitable difference, field test is required on operating performance of solar water heating system so as to understand actual operating feature of the system, to improve its actual operating effect, and to analyze its energy saving benefit and environmental benefit. The paper makes field test on distributed solar water heating system of certain high-rise building in Jinan City according to "Acceptance and Assessment Methods of Application Demonstration Cities and Counties of Renewable Energy Buildings” Jianke [2014] No. $138^{[1]}$, GB/T 50801-2013 "Standard on Evaluation of Application Projects of Renewable Energy Buildings" [2] and DB37/T 2397-2013 "Standard on Inspection and Evaluation of Application Projects of Renewable Energy Buildings”, and obtains its energy saving effect.

\section{Distributed solar water heating system of certain high-rise building in Jinan City}

\section{Project introduction}

The high-rise building has 3 buildings in total and total building area of 39,300 square meters, and includes 18 above-ground stories and 2 underground stories. There are total 432 households, the households use flat plate separated type solar water heating system with same brand and same specification provide living hot water.

Distributed flat plate separated type solar water heating system way is used to provide hot water to the households, and 432 solar water heating systems are designed and installed. Nominal capacity of water tank of selected solar water heating system is $100 \mathrm{~L}$, nominal daylight area of solar collector is $1.87 \mathrm{~m}^{2}$. 


\section{Field test of water heating system}

\section{Test plan}

The high-rise building has total 432 households. Solar water heating system of Room 1207, Unit 2, Building A1\#, Room 1406, Unit 2, Building A2\# and Room 1402, Unit 1, Building 31\# are selected for test, and test time is from June 8, 2015 to June 11, 2015.

2 Test contents

Performance test of household solar water heating system: heat gain of heat collecting system, efficiency of heat collecting system and solar guarantee rate.

Energy efficiency assessment of household solar water heating system: energy saving benefit.

\section{Field test method and data processing of solar water heating system}

1 Test method and data processing of heat gain of heat collecting system

Heat gain of heat collecting system is calculated by following formula:

$Q_{\mathrm{j}}=\rho_{\mathrm{w}} c_{\mathrm{pw}} V_{\mathrm{s}}\left(t_{\mathrm{e}}-t_{\mathrm{b}}\right)$

Among it:

$Q_{\mathrm{j}}$ - heat gain of heat collecting system (MJ);

$\rho_{\text {w }}$ - density of water $\left(\mathrm{kg} / \mathrm{m}^{3}\right)$;

$C_{\mathrm{pw}}$ - specific heat capacity of water $[\mathrm{kJ} /(\mathrm{kg} \cdot \mathrm{K})]$;

$V_{\mathrm{s}}$ - water capacity of hot water tank $\left(\mathrm{m}^{3}\right)$;

$t_{\mathrm{b}}$ - Water temperature in hot water tank when test starts $\left({ }^{\circ} \mathrm{C}\right)$;

$t_{\mathrm{e}}$ - Water temperature in hot water tank when test finishes $\left({ }^{\circ} \mathrm{C}\right)$.

2 Data processing and calculation of conventional heat source energy consumption of system

Since solar water heating system doesn't need auxiliary electrical heating during summer test, conventional heat source energy consumption of system is obtained by theoretical calculation. According to "Design Manual of Water Supply and Drainage of Buildings" [4], bath water temperature shall be $50^{\circ} \mathrm{C}-65^{\circ} \mathrm{C}$, and calculation is now made by $60^{\circ} \mathrm{C}$. If water temperature in hot water tank can't reach $60^{\circ} \mathrm{C}$ when heat collection finishes, auxiliary electrical heating starts.

Conventional heat source energy consumption of system is calculated by following formula:

$Q_{\mathrm{fz}}=\rho_{\mathrm{w}} C_{\mathrm{pw}} V_{\mathrm{s}}\left(t_{\mathrm{s}}-t_{\mathrm{e}}\right)$

Among it:

$Q_{\mathrm{fz}}$ - conventional heat source energy consumption of system (MJ);

$\rho_{\mathrm{w}}$ - density of water $\left(\mathrm{kg} / \mathrm{m}^{3}\right)$;

$c_{\mathrm{pw}}$ - specific heat capacity of water $[\mathrm{kJ} /(\mathrm{kg} \cdot \mathrm{K})]$;

$V_{\mathrm{s}}$ - water capacity of hot water tank $\left(\mathrm{m}^{3}\right)$;

$t_{\mathrm{e}}$ - Water temperature in hot water tank when test finishes $\left({ }^{\circ} \mathrm{C}\right)$;

$t_{\mathrm{s}}$ - bath water design temperature $\left({ }^{\circ} \mathrm{C}\right)$.

3 Test method and data processing of efficiency of heat collecting system

3.1 Test method of relevant parameters

1 Test method of heat gain of heat collecting system $Q_{\mathrm{j}}$, same as 3.1.

2 Test method of daily solar radiation quantity $J$

One pyranometer is installed by same tilting angle of solar collector. The pyranometer records daily solar radiation quantity automatically, dividing the value daylight area of solar collector contour obtains daily solar radiation quantity $J$, which is projected on lighting surface of solar 
collector contour during effective test period.

3 Calculation method of daylight area of flat plate type solar collector contour

By calculation according to the stipulations of GB/T 19141-2003 “Technical Conditions of Household Solar Water Heating Systems" [5], calculation formula of daylight area of flat plate type solar collector contour $A_{\mathrm{c}}$ is:

$$
A_{c}=L \times W
$$

Among it,

$L$ - length of daylight opening of flat plate type solar collector (m);

$W$ - width of daylight opening of flat plate type solar collector (m).

3.2 Data processing and calculation of efficiency of heat collecting system

Efficiency of heat collecting system is calculated by following formula:

$$
\eta=\frac{Q_{\mathrm{j}}}{A_{\mathrm{c}} J}
$$

Among it:

$\eta$ - efficiency of heat collecting system (\%);

$Q_{\mathrm{j}}$ - heat gain of solar heat collecting system during test period (MJ);

$A_{c}$ - daylight area of solar collector contour $\left(\mathrm{m}^{2}\right)$;

$J$ - solar radiation quantity on solar collector lighting surface per square meter during test period $\left(\mathrm{MJ} / \mathrm{m}^{2}\right)$.

4 Calculation of solar guarantee rate

Solar guarantee rate of the system is calculated by following formula:

$$
f=\frac{Q_{\mathrm{j}}}{Q_{\mathrm{z}}}
$$

Among it:

$f$ - solar guarantee rate (non-dimensional);

$Q_{\mathrm{j}}$ - heat gain of solar heat collecting system (MJ);

$Q_{\mathrm{z}}$ - heat of the system to be supplied to the user (MJ), $Q_{\mathrm{z}}=Q_{\mathrm{j}}+Q_{\mathrm{fz}}$.

5 Test results

Heat gain of heat collecting system, efficiency of heat collecting system and solar guarantee rate of three solar water heating systems are obtained by calculation, and data analysis and energy efficiency assessment are made by taking test results of household solar water heating system of Room 1207, Unit 2, Building A1\# as example. 
Table1 Test results of household solar water heating system of Room 1207, Unit 2, Building A1\#

\begin{tabular}{|c|c|c|c|c|c|c|c|c|c|}
\hline Test date & $\begin{array}{l}\text { Ambi } \\
\text { ent air } \\
\text { averag } \\
\text { e } \\
\text { tempe } \\
\text { rature } \\
{ }^{\circ} \mathrm{C}\end{array}$ & $\begin{array}{c}\text { Ambi } \\
\text { ent air } \\
\text { averag } \\
\text { e wind } \\
\text { speed } \\
\mathrm{m} / \mathrm{s}\end{array}$ & $\begin{array}{c}\text { Solar } \\
\text { radiati } \\
\text { on } \\
\text { quanti } \\
\text { ty } \\
\mathrm{MJ} / \mathrm{m}^{2}\end{array}$ & $\begin{array}{c}\text { Water } \\
\text { tempe } \\
\text { rature } \\
\text { in hot } \\
\text { water } \\
\text { tank } \\
\text { when } \\
\text { test } \\
\text { starts } \\
{ }^{\circ} \mathrm{C}\end{array}$ & $\begin{array}{c}\text { Water } \\
\text { tempe } \\
\text { rature } \\
\text { in hot } \\
\text { water } \\
\text { tank } \\
\text { when } \\
\text { test } \\
\text { finish } \\
\text { es } \\
{ }^{\circ} \mathrm{C}\end{array}$ & $\begin{array}{l}\text { Heat } \\
\text { gain } \\
\text { of } \\
\text { heat } \\
\text { collect } \\
\text { ing } \\
\text { syste } \\
\text { m } \\
\text { MJ }\end{array}$ & $\begin{array}{c}\text { Conve } \\
\text { ntiona } \\
\text { l heat } \\
\text { source } \\
\text { energ } \\
y \\
\text { consu } \\
\text { mptio } \\
\text { n of } \\
\text { syste } \\
\text { m } \\
\text { MJ }\end{array}$ & $\begin{array}{c}\text { Effici } \\
\text { ency } \\
\text { of } \\
\text { heat } \\
\text { collect } \\
\text { ing } \\
\text { syste } \\
\text { m } \\
\%\end{array}$ & $\begin{array}{c}\text { Solar } \\
\text { guara } \\
\text { ntee } \\
\text { rate } \\
\%\end{array}$ \\
\hline $2015 / 6 / 8$ & 31.2 & 1.3 & 6.4 & 24.8 & 35.7 & 4.4 & 9.6 & 35.8 & 31.4 \\
\hline $2015 / 6 / 9$ & 31.5 & 1.8 & 9.4 & 22.7 & 38.8 & 6.4 & 8.4 & 35.5 & 43.2 \\
\hline $2015 / 6 / 10$ & 30.2 & 1.5 & 12.4 & 26.3 & 47.5 & 8.4 & 4.9 & 35.3 & 63.2 \\
\hline 2015/6/11 & 29.1 & 1.3 & 16.6 & 22.3 & 50.5 & 11.2 & 3.8 & 35.1 & 74.7 \\
\hline
\end{tabular}

\section{Energy efficiency assessment of solar water heating system}

1 Annual solar guarantee rate

Measured solar radiation quantities are $J_{1}, J_{2}, J_{3}$ and $J_{4}$ from small to large. According to statistics, days whose local daily solar radiation quantity is less than $8 \mathrm{MJ} / \mathrm{m}^{2}$ is $X_{1}$; days whose local daily solar radiation quantity is less than $12 \mathrm{MJ} / \mathrm{m}^{2}$ and equal to or more than $8 \mathrm{MJ} / \mathrm{m}^{2}$ is $X_{2}$; days whose local daily solar radiation quantity is less than $16 \mathrm{MJ} / \mathrm{m}^{2}$ and equal to or more than 12 $\mathrm{MJ} / \mathrm{m}^{2}$ is $X_{3}$; days whose local daily solar radiation quantity is equal to or more than $16 \mathrm{MJ} / \mathrm{m}^{2}$ is $X_{4}$.

By test, solar guarantee rate whose local daily solar radiation quantity is less than $8 \mathrm{MJ} / \mathrm{m}^{2}$ is $f_{1}$; solar guarantee rate whose local daily solar radiation quantity is less than $12 \mathrm{MJ} / \mathrm{m}^{2}$ and equal to or more than $8 \mathrm{MJ} / \mathrm{m}^{2}$ is $f_{2}$; solar guarantee rate whose local daily solar radiation quantity is less than $16 \mathrm{MJ} / \mathrm{m}^{2}$ and equal to or more than $12 \mathrm{MJ} / \mathrm{m}^{2}$ is $f_{3}$; solar guarantee rate whose local daily solar radiation quantity is equal to or more than $16 \mathrm{MJ} / \mathrm{m}^{2}$ is $f_{4}$. Annual solar guarantee rate $f$ is calculated by following formula:

$$
f=\frac{X_{1} f_{1}+X_{2} f_{2}+X_{3} f_{3}+X_{4} f_{4}}{X_{1}+X_{2}+X_{3}+X_{4}}
$$


Table 2 Annual solar guarantee rate of household solar water heating system of Room 1207, Unit 2, Building A1\#

\begin{tabular}{|c|c|c|c|c|}
\hline \multirow{2}{*}{ Test item } & \multicolumn{3}{|c|}{ Local daily solar radiation quantity $\left(\mathrm{MJ} / \mathrm{m}^{2}\right)$} \\
\cline { 2 - 5 } & $J<8$ & $8 \leq J<12$ & $12 \leq J<16$ & $J \geq 16$ \\
\hline Days $\left(X_{1}, X_{2}, X_{3}, X_{4}\right)$ & 51 & 65 & 116 & 133 \\
\hline $\begin{array}{l}\text { Measured solar guarantee rate on } \\
\text { the same day }\left(f_{1}, f_{2}, f_{3}, f_{4}\right)\end{array}$ & $31.4 \%$ & $43.2 \%$ & $63.2 \%$ & $74.7 \%$ \\
\hline \multicolumn{5}{|c|}{$57.7 \%$} \\
\hline
\end{tabular}

2 Conventional energy substitution quantity (ton standard coal)

Measured solar radiation quantities are $J_{1}, J_{2}, J_{3}$ and $J_{4}$ from small to large. According to statistics, days whose local daily solar radiation quantity is less than $8 \mathrm{MJ} / \mathrm{m}^{2}$ is $X_{1}$; days whose local daily solar radiation quantity is less than $13 \mathrm{MJ} / \mathrm{m}^{2}$ and equal to or more than $8 \mathrm{MJ} / \mathrm{m}^{2}$ is $X_{2}$; days whose local daily solar radiation quantity is less than $18 \mathrm{MJ} / \mathrm{m}^{2}$ and equal to or more than 13 $\mathrm{MJ} / \mathrm{m}^{2}$ is $X_{3}$; days whose local daily solar radiation quantity is equal to or more than $18 \mathrm{MJ} / \mathrm{m}^{2}$ is $X_{4}$.

By test, heat gain of heat collecting system whose local daily solar radiation quantity is less than $8 \mathrm{MJ} / \mathrm{m}^{2}$ is $Q_{\mathrm{j} 1}$; heat gain of heat collecting system whose local daily solar radiation quantity is less than $13 \mathrm{MJ} / \mathrm{m}^{2}$ and equal to or more than $8 \mathrm{MJ} / \mathrm{m}^{2}$ is $Q_{\mathrm{j} 2}$; heat gain of heat collecting system whose local daily solar radiation quantity is less than $18 \mathrm{MJ} / \mathrm{m}^{2}$ and equal to or more than $13 \mathrm{MJ} / \mathrm{m}^{2}$ is $Q_{\mathrm{j} 3}$; heat gain of heat collecting system whose local daily solar radiation quantity is equal to or more than $18 \mathrm{MJ} / \mathrm{m}^{2}$ is $Q_{\mathrm{j} 4}$.

Annual conventional energy substitution quantity is calculated by following formula:

$$
Q_{\mathrm{tr}}=\frac{X_{1} Q_{1}+X_{2} Q_{2}+X_{3} Q_{3}+X_{4} Q_{4}}{29.308 \times 0.33 \times 1000}
$$

Table 3 Conventional energy substitution quantity of household solar water heating system of

Room 1207, Unit 2, Building A1\#

\begin{tabular}{|c|c|c|c|c|}
\hline \multirow{2}{*}{ Test item } & \multicolumn{4}{|c|}{ Local daily solar radiation quantity $\left(\mathrm{MJ} / \mathrm{m}^{2}\right)$} \\
\hline & $J<8$ & $8 \leq J<12$ & $12 \leq J<16$ & $J \geq 16$ \\
\hline Days $\left(X_{1}, X_{2}, X_{3}, X_{4}\right)$ & 51 & 65 & 116 & 133 \\
\hline $\begin{array}{l}\text { Measured heat gain of heat } \\
\text { collecting system on the same day } \\
\left(Q_{\mathrm{j} 1}, Q_{\mathrm{j} 2}, Q_{\mathrm{j} 3}, Q_{\mathrm{j} 4}\right)\end{array}$ & 4.4 & 6.4 & 8.4 & 11.2 \\
\hline $\begin{array}{l}\text { Calculating heat gain of project } \\
\text { whole heat collecting system }\left(Q_{1} \text {, }\right. \\
\left.\qquad Q_{2}, Q_{3}, Q_{4}\right)\end{array}$ & $1,900.8$ & $2,764.8$ & $3,628.8$ & $4,838.4$ \\
\hline $\begin{array}{l}\text { Annual conventional energy } \\
\text { substitution quantity } \\
\text { standard coal) }\end{array}$ & \multicolumn{4}{|c|}{150.7} \\
\hline \multicolumn{5}{|c|}{$\begin{array}{l}\text { Measured solar radiation quantity in four days is } J_{1}=6.4 \mathrm{MJ} / \mathrm{m}^{2}, J_{2}=9.4 \mathrm{MJ} / \mathrm{m}^{2}, J_{3}= \\
12.4 \mathrm{MJ} / \mathrm{m}^{2}, J_{4}=16.6 \mathrm{MJ} / \mathrm{m}^{2} \text {. }\end{array}$} \\
\hline
\end{tabular}

\section{Conclusion}

It can be seen by 4-day follow-up test on 3 flat plate separated type solar water heating systems of the high-rise building, and according to energy efficiency assessment on test data of household 
solar water heating system of Room 1207, Unit 2, Building A1\#:

Annual solar guarantee rate of solar water heating system of the high-rise building is $57.7 \%$, which meets the stipulation of not less than 40\% in GB/T 50801-2013 "Standard on Evaluation of Application Projects of Renewable Energy Buildings”.

Standard coal saving quantity of solar water heating system of the high-rise building is 150.7 ton/year, and it has good energy saving benefit and economic benefit.

\section{References:}

[1] “Acceptance and Assessment Methods of Application Demonstration Cities and Counties of Renewable Energy Buildings” Jianke [2014] No. 138

[2] GB/T "Standard on Evaluation of Application Projects of Renewable Energy Buildings"

[3] DB37/T 2397-2013 "Standard on Inspection and Evaluation of Application Projects of Renewable Energy Buildings"

[4] "Design Manual of Water Supply and Drainage of Buildings"

[5] GB/T 19141-2003 “Technical Conditions of Household Solar Water Heating Systems” 